\title{
Comparison of reproductive performance of Clarias batrachus (Linnaeus, 1758) collected from three Indian rivers
}

\author{
RAVI CHARAN ${ }^{1}$, KIRAN DUBE ${ }^{2}$, P. P. SURESH BABU ${ }^{3}$, S. DAM ROY ${ }^{4}$, RUPAM SHARMA², \\ P. SRINIVASA RAO ${ }^{5}$, J. KRISHNA PRASAD 5 AND J. RAYMOND JANI ANGEL ${ }^{4}$ \\ ${ }^{1}$ Peninsular and Marine Fish Genetic Resources Centre, National Bureau of Fish Genetic Resources, ICAR-Central Marine \\ Fisheries Research Institute Campus, Kochi - 682 018, Kerala, India \\ ${ }^{2}$ ICAR-Central Institute of Fisheries Education, Versova, Mumbai - 400 061, Maharashtra, India \\ ${ }^{3}$ Calicut Research Centre of ICAR-Central Marine Fisheries Research Institute, Calicut - 673 005, Kerala, India \\ ${ }^{4}$ ICAR-Central Island Agricultural Research Institute, Port Blair - 744 101, Andaman and Nicobar Islands, India \\ ${ }^{5}$ Kakinada Research Centre of ICAR-Central Institute of Fisheries Education, Kakinada - 533 001, Andhra Pradesh, India \\ e-mail: kirandr@cife.edu.in
}

\begin{abstract}
A study was conducted to compare the reproductive performance of Clarias batrachus (Linnaeus, 1758) collected from three different rivers viz., Krishna in Andhra Pradesh, Godavari in Maharashtra and Narmada in Madhya Pradesh. Twenty pairs of brooders from each location were randomly selected and induced with pituitary extract $(\mathrm{P})$ and ovaprim $(\mathrm{O})$. Reproductive performance in terms of stripping percentage, pseudo gonado-somatic index, spawning, fecundity, fertilisation rate, hatching rate, and survival rate as well as fry rearing performance in terms of percentage weight gain, specific growth rate (SGR) and survival rate were monitored. Brooders collected from Godavari exhibited significantly $(\mathrm{p}<0.05)$ higher values for all the reproductive performances indicators compared to brooders collected from Narmada and Krishna rivers. But fishes collected from Krishna River exhibited significantly higher $(\mathrm{p}<0.05)$ fry survival. Fry produced from Godavari brooders attained highest $(p<0.05)$ percentage weight gain $(1085.88 \pm 37.41)$, SGR $(17.61 \pm 0.19)$ and fry survival rate $(43.67 \pm 1.45)$ in comparison to Narmada. Results clearly indicated that reproductive performance varied significantly among the brooders collected from the three different rivers.
\end{abstract}

Keywords: Brooders, Clarias batrachus, Ovaprim, Pituitary extract, Reproductive performance

\section{Introduction}

Among the indigenous catfishes, Clarias batrachus (Linnaeus, 1758), commonly known as magur, is one of the commercially important species in India. Culture of this species has been identified as a national priority owing to its good demand, decline in fishery, hardy nature and aquaculture potential (Sharma et al., 2010). Magur breeds once in a year during June to August in the natural environment. However, population of this species has been reduced drastically during recent years due to overfishing, habitat alterations and indiscriminate use of pesticides in preferred natural breeding grounds such as paddy fields and wetlands (Goswami, 2007; Khedkar et al., 2010). This species is classified under threatened category (Argungu et al., 2013), warranting the need for conservation and sustainable management.

Studies on different aspects in captive breeding of C. batrachus has been carried out, such as optimisation of breeding using different inducing agents (Sahoo et al., 2005; Hossain et al., 2006; Jagtap et al., 2015), standardisation of latency period (Sahoo et al., 2007; Jagtap et al., 2015) and stripping response with different inducing agents (Sahoo et al., 2007). However the quality of seed produced and breeding performance in captivity cannot be assured due to poor quality of brooders and lack of sufficient knowledge on reproductive traits in wild condition, resulting in over dependency on wild seed for stocking in ponds which is uneconomical and less sustainable (Kiran et al., 2013).

Knowledge on reproductive parameters is a prerequisite for designing proper management measures in sustainable aquaculture (Fostier and Jalabert, 2004; Morgan, 2008) and reproductive performance has been evaluated in several fish species (Kamler, 2005; Teletchea et al., 2009). Inter-population variation in relation to reproductive traits in Salmo trutta (Linnaeus 1758) was analysed by Labie-lund and Hindar (1990). Bagenal, (1971) studied the effect of geographical variation on reproductive traits in fishes. Similarly several studies evaluated the reproductive parameters among various populations in order to find out the reproductively superior population (Estay et al., 2004; Alonso-Fernandez et al., 2013). 
Genetic variation among magur populations from various rivers have been documented in India and Bangladesh (Islam et al., 2007; Garg et al., 2010 and Khedkar et al., 2016). But no study has been carried out so far on the breeding performance of this species across different geographical locations in Indian waters. In this backdrop, the present study on reproductive performance of magur from three different rivers in India, evaluated the differences in reproductive potential of these geographically isolated fishes.

\section{Materials and methods}

\section{Fish collection and maintenance}

Adult C. batrachus, ( $\sim 70$ nos. each) were collected from three different rivers in India viz., Krishna River from Vijayawada District in Andhra Pradesh (AP), Godavari from Chandrapur District of Maharashtra (MH) and Narmada from Bhopal District in Madhya Pradesh (MP) during April - May 2012. Breeding experiments were conducted in earthern ponds of the freshwater fish farm of the Kakinada Research Centre of ICAR-Central Institute of Fisheries Education (ICAR-CIFE), Andhra Pradesh. The fishes were separated based on collection source as well as sex and maintained in earthen ponds of $200 \mathrm{~m}^{2}$ (water depth $1 \mathrm{~m}$ ) for one month and were fed with farm made feed containing $35 \%$ protein.

\section{Breeding of magur by hormonal inducement}

Breeding trials of magur collected from different locations were carried out during July 2012. Females having soft, bulging gravid abdomen with reddish vent, round button shaped genital papilla and males with increased vascularisation on the pointed genital papilla (Sahoo et al., 2005), were used for the breeding programme. Twenty pairs of brooders from each habitat were selected for breeding. One set of ten pairs of brooders each from all the three locations were injected with carp pituitary extract $(\mathrm{P})$ and a second set of ten pairs each were given ovaprim $(\mathrm{O})$. Before giving injection, total length $(\mathrm{cm})$ and total weight $(\mathrm{g})$ were recorded. Carp pituitary extract was prepared according to Bhowmick (1990) and female brooders were given intra-muscular injection @,50 mg kg-1 body weight (Goswami and Sarma, 1997; Sahoo et al., 2013). Synthetic inducing agent ovaprim (M/s Syndel Laboratories, Canada) was administered at a dose of $1 \mathrm{ml}$ $\mathrm{kg}^{-1}$ of body weight of female (Srivastava et al., 2012). Males were given half the dose of respective inducing agent. After injection, males and females were kept separately in plastic tubs holding 251 pond water.

\section{Reproductive performance analysis}

After the optimum latency period of 14-17 h (Sahoo et al., 2007), stripping and artificial fertilisation were carried out. Males were sacrificed and the testes were carefully removed, cut into small pieces, squeesed and mixed with physiological saline solution. Simultaneously the females were stripped and eggs were collected in small clean and dry plastic trays. A batch of small quantity of eggs was transferred to a pre-weighed petriplate and weighed in an electronic balance (with an accuracy of $0.002 \mathrm{~g}$ ), for further analysis of breeding parameters. Before and after stripping, weight of the fishes was noted to aid in estimation of stripped egg weight, stripping percentage, pseudo gonado-somatic index (PGSI) and spawning fecundity. Stripping percentage was calculated according to Brzuska (2003) and PGSI was determined as per Abdulraheem et al. (2012). Spawning fecundity in each set was calculated as per Hossain and Islam (1990). Ova diameter studies were carried out using 30 eggs from each individual female using an ocular micrometer. Fertilisation rate was calculated following Adebayo and Popoola (2008).

Hatching and larval rearing of magur was carried out in the model magur hatchery at Kakinada Centre of ICARCIFE. Fertilised eggs were collected on Eichhornia roots and shifted to rectangular FRP troughs (4.1' x1.6' $\mathrm{x} 0.65^{\prime}$ having a steady water level of $8 \mathrm{~cm}$ ) provided with flowthrough system and aeration. Hatching was completed between 24 and $28 \mathrm{~h}$ post-fertilisation and the hatching rate was determined by counting the number of two days old hatchlings according to Haniffa and Sridhar (2002). Rearing of hatchlings was carried out in the flow-through system till $4^{\text {th }}$ day of stocking with a stocking rate of $2000 \pm 200$ hatchlings per trough, provided with newly hatched Artemia nauplii as feed @20-25 nauplii per larva, four times a day. Stocking density was reduced to $1000 \pm 100$ hatchlings per trough till $12^{\text {th }}$ day until the appearance of frequent vertical movements of fry and they were fed with mixed zooplankton (dominated by Moina sp.) @ $5 \mathrm{ml}$ per trough (500 cells $\mathrm{ml}^{-1}$ ) and tubifex worms at $15 \%$ of body weight. Uneaten food was removed after $30 \mathrm{~min}$. At the end of larval rearing, survival of fish was estimated according to Shinkafi and Ilesanmi (2014).

\section{Fry rearing trials}

Magur fry were reared in rectangular FRP tanks (6' $\times 2$ ' $\left.\times 1.5^{\prime}\right)$, provided with aeration. Early fry were stocked at 250 nos. per tank in three replicates. The length and weight of 25 larvae were recorded using a measuring scale and electronic balance respectively, prior to stocking and at weekly intervals during rearing. A steady water level of $25 \mathrm{~cm}$ was maintained in the tanks and PVC pipes were placed in the tanks to provide shelter for the fishes. Every day tanks were cleaned and about $10-20 \%$ water was exchanged daily. The fishes were fed with mixed zooplankton (dominated by Moina sp.)@ $10 \mathrm{ml}$ per trough (500 cells ml $\left.{ }^{-1}\right)$ along with crumbled feed $(150 \mu)$ having $40 \%$ protein and tubifex worm at $10 \%$ of body weight three times a day) during entire rearing period. Faecal waste and dead larvae were removed before the next feeding. At the end of two weeks of rearing, all survived fry were collected and enumerated. The percentage 
weight gain, survival rate and specific growth rate (SGR) were calculated according to Sahoo et al. (2004).

Physico-chemical parameters of water in the hatchery unit were analysed daily following standard protocols (APHA, 2000).

\section{Statistical analysis}

Statistical analysis of the data was carried out using Statistical Package for the Social Sciences (SPSS) software, version 16.0. Differences in breeding parameters among three groups of magur were tested using one-way analysis of variance (ANOVA) followed by a Tukey's test at 5\% level of significance.

\section{Results and discussion}

Physico - chemical parameters of water in the breeding and larval rearing systems viz., temperature, dissolved oxygen, total alkalinity and $\mathrm{pH}$ recorded were: $26-28^{\circ} \mathrm{C}$, 7-7.5 ppm, 110-130 ppm and 7.5 - 7.8 respectively and were well within the optimum range (Tucker, 1991) and were uniform for all the stocks.

The study was conducted during the peak breeding period of the species and the reproductive indices such as weight of stripped eggs, stripping percentage, spawning fecundity, PGSI and ova diameter (Table 1) were recorded for the two different inducing agents viz., ovaprim and pituitary extract separately. The pituitary gland produces and stores gonadotropin hormones $(\mathrm{GtH})$, which play a decisive role in ovulation and spermiation (Rottmann et al., 1991). Ovaprim, a synthetic gonadotropin releasing hormone $(\mathrm{GnRH})$, triggers pituitary to produce $\mathrm{GtH}$ which is necessary for spawning (Rottmann et al., 1991; Yanong et al., 2009). Although the mode of action of these inducing agents are different, the results of all parameters indicating breeding performance, obtained in the present study were almost similar.

In the present study, the average spawning fecundity of magur was observed in the range of $3600 \pm 274.16$ to $9539 \pm 746.50$, similar to the earlier studies (Goswami, 2007; Sahoo et al., 2007; Jatpat et al., 2015). Higher weight of stripped eggs and spawning fecundity were noted for magur from Godavari followed by Krishna River for both pituitary and ovaprim inducement, whereas the value observed for magur from Narmada was found to be significantly lower $(\mathrm{p}<0.05)$ for both the inducing agents. Stripping percentage also varied significantly $(\mathrm{p}<0.05)$ among the fish collected from different rivers and was highest in magur from Godavari $[14.57 \pm 1.026(\mathrm{P}) ; 11.82 \pm 0.184(\mathrm{O})]$, followed by Krishna [9.74 $\pm 0.286(\mathrm{P}) ; 9.90 \pm 1.149(\mathrm{O})]$ and Narmada [10.04 $\pm 0.498(\mathrm{P}) ; 9.17 \pm 0.457(\mathrm{O})]$. Similar values were observed in closely related species Clarias gariepinus (De Graaf et al., 1995; Shinkafi and Ilesanmi, 2014). Since stripping process was involved in the breeding programme, PGSI is employed as an index in the present study according to Oyelese (2006) instead of GSI. From the Table 1, it is evident that PGSI was significantly higher $(\mathrm{p}<0.05)$ in Godavari group compared to Krishna and Narmada. Ova diameter of magur collected from Narmada [110.84 $\pm 0.30 \mu$ $(\mathrm{P}) ; 110.73 \pm 0.23 \mu(\mathrm{O})]$ was found to be significantly higher $(\mathrm{p}<0.05)$ than Krishna and Godavari. Cheah et al. (1990) reported an ova diameter of $99.0 \pm 0.11 \mu$ to $127 \pm 0.18 \mu$ during ovulation; while, Thakur (1980) reported an ova diameter of $150 \mu$ indicating variation in ova diameter.

Fertilisation rate (Fig. 1) of magur from Godavari was highest $(\mathrm{p}<0.05)(69.33 \pm 1.99)$; whereas that of Narmada was the lowest (46.67 \pm 1.79$)$. Fertilisation rate of $60-75 \%$ and 70 $72 \%$ were reported in magur by Rao and Jankiram (1991) and Srivastava et al. (2012) respectively. Hatching rate (Fig. 2) for magur from Godavari was found significantly higher $(\mathrm{p}<0.05) \quad(59 \pm 2.09)$, while magur from Narmada had lowest values (38.67 \pm 0.75$)$. Rao and Jankiram (1991) reported a hatching rate in the range of $30-45 \%$, while Srivastava et al. (2012) and Sharma et al. (2010) reported a range of $50-55 \%$ in C. batrachus. Survival rate of fry

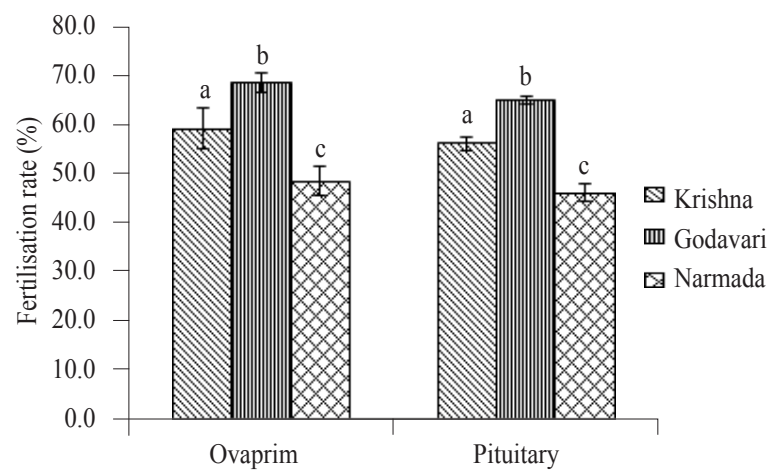

Fig.1. Fertilization rate (mean \pm SE) of Clarias batrachus collected from different rivers. Bars with same superscripts do not differ significantly $(\mathrm{p}>0.05)$

Table 1. Reproductive indices of Clarias batrachus collected from different Indian rivers.

\begin{tabular}{|c|c|c|c|c|c|c|c|c|c|c|c|c|c|c|}
\hline \multirow[t]{2}{*}{ Rivers } & \multicolumn{2}{|c|}{ Length $(\mathrm{cm})$} & \multicolumn{2}{|c|}{ Weight (g) } & \multicolumn{2}{|c|}{ Weight of stripped eggs ( $g$ ) } & \multicolumn{2}{|c|}{ Stripping \% } & \multicolumn{2}{|c|}{ Spawning fecundity } & \multicolumn{2}{|c|}{ PGSI } & \multicolumn{2}{|c|}{ Ova diameter $(\mu)$} \\
\hline & PE & Ovaprim & PE & vaprim & PE & Ovaprim & $\mathrm{PE}$ & Ovaprim & PE & Ovaprim & PE & Ovaprim & PE & Ovaprim \\
\hline & 4 & $2^{\mathrm{a}}$ & $200.67 \pm 7.41^{\mathrm{a}}$ & $67 \pm 3.07$ & & $49^{\mathrm{a}}$ & & $49^{\mathrm{a}}$ & $8910 \pm 624.71^{\mathrm{a}}$ & 11.16 & 10.6 & $6^{a}$ & 100.2 & 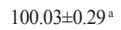 \\
\hline dav & $5.0 \pm 0.30^{\mathrm{b}}$ & $26.17 \pm 0.23^{\mathrm{b}}$ & $152.50 \pm 2.51^{b}$ & $165.67 \pm 3.17^{b}$ & $22.13 \pm 1.39^{\mathrm{a}}$ & $19.57 \pm 0.47^{\mathrm{a}}$ & $14.57 \pm 1.026^{b}$ & $11.82 \pm 0.104^{b}$ & $9539 \pm 746.50^{\mathrm{a}}$ & $8114 \pm 179.67^{a}$ & $17.20 \pm 1.48^{b}$ & $13.41 \pm 0.27^{\mathrm{b}}$ & $102.6 \pm 1.66^{\mathrm{a}}$ & $103.34 \pm 1.06^{b}$ \\
\hline armada & $26.08 \pm 0.60^{\mathrm{b}}$ & $27 \pm 0.30^{\mathrm{b}}$ & $154.33 \pm 3.85^{\mathrm{b}}$ & $166 \pm 1.86^{\mathrm{b}}$ & $15.42 \pm 0.47^{\mathrm{b}}$ & $15.20 \pm 0.66^{\mathrm{b}}$ & $10.04 \pm 0.498^{\mathrm{a}}$ & $9.17 \pm 0.457^{\mathrm{a}}$ & $5160 \pm 147.48^{\mathrm{b}}$ & $3600 \pm 274.16^{\mathrm{b}}$ & $11.26 \pm 0.72^{\mathrm{a}}$ & $10.16 \pm 0.61^{\text {ac }}$ & $110.8 \pm 0.30^{\mathrm{b}}$ & $110.73 \pm 0.23^{c}$ \\
\hline
\end{tabular}

The values (mean \pm SE) bearing same superscript do not differ significantly $(p>0.05)$ 


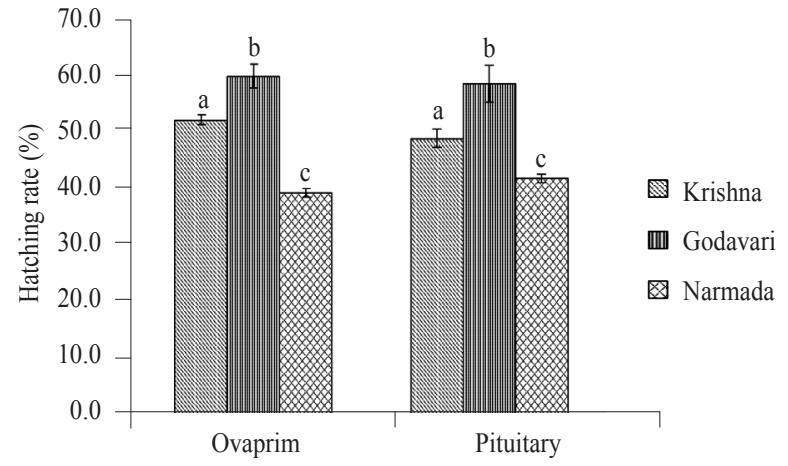

Fig. 2. Hatching rate (mean $\pm \mathrm{SE}$ ) of Clarias batrachus collected from different rivers. Bars with same superscripts do not differ significantly $(\mathrm{p}>0.05)$

$\left(12^{\text {th }}\right.$ day) produced from magur collected from different rivers is given in Fig. 3. Survival rate was highest in magur from Krishna $(65.81 \pm 0.9)(\mathrm{p}<0.05)$ followed by Godavari $(56 \pm 0.79)$ and the lowest value was observed in Narmada group $(44.87 \pm 1.06)$.

The fry rearing performance indices such as final length and weight, percentage weight gain, SGR and survival rate were recorded after 14 days of rearing (Table 2). Magur fry from Godavari group exhibited higher performance compared to Narmada group $(\mathrm{p}<0.05)$.

Our results from breeding trials revealed that the reproductive performance of fish collected from Godavari is better than Narmada and Krishna $(\mathrm{p}<0.05)$. In fry rearing trial, Godavari and Krishna groups exhibited no significant difference between them, whereas both the populations exhibited significantly different performance as compared to Narmada population. Various studies have reported on the intra-specific variation in different reproductive parameters

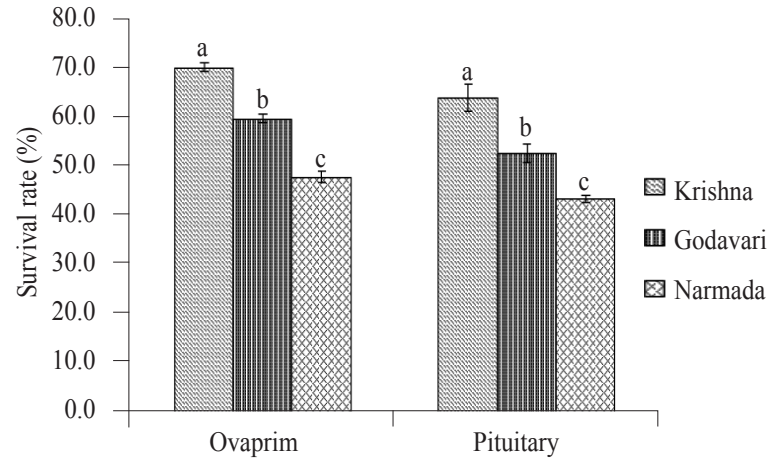

Fig. 3. Survival rate (mean $\pm \mathrm{SE}$ ) of fry produced from Clarias batrachus collected from different rivers. Bars with same superscripts do not differ significantly $(\mathrm{p}>0.05)$

in fishes viz., Poecilia reticulata (Peters, 1860) (Svendsen et al., 2013); Lacerta vivipara (Von Jacquin, 1787) (Bauwens and Verheyen, 1987) and in several European freshwater fishes (Blanck et al., 2007). The present findings in magur from Indian rivers indicate variations in reproductive parameters between populations of same species.

Control of reproduction is a prerequisite for domestication of fish populations. Hence it is essential to evaluate differences in selected reproductive parameters between populations of same species, prior to undertaking large scale breeding and domestication programmes for aquaculture. Our study highlights the differential performance of reproductive parameters in magur populations from three Indian rivers indicating better reproductive capacity of brooders from river Godavari in comparison to brooders from Krishna and Narmada rivers. The knowledge generated will be of use in choosing brooders of magur, C. batrachus with superior reproductive traits for designing breeding plans for sustainable aquaculture development in the country.

Table 2. Fry rearing performance of Clarias batrachus from different rivers during two weeks of rearing period.

\begin{tabular}{llllllll}
\hline Rivers & Initial length $(\mathrm{mm})$ & Initial weight $(\mathrm{mg})$ & Final length $(\mathrm{mm})$ & Final weight $(\mathrm{mg})$ & $\%$ Weight gain & SGR $(\%)$ & Survival rate \\
\hline Krishna & $12.27 \pm 0.88^{\mathrm{a}}$ & $19.76 \pm 0.66^{\mathrm{a}}$ & $26.75 \pm 1.27^{\mathrm{a}}$ & $210.91 \pm 24.29^{\mathrm{a}}$ & $975.21 \pm 29.14^{\mathrm{a}}$ & $16.93 \pm 0.24^{\mathrm{a}}$ & $39.16 \pm 1.4^{\mathrm{a}}$ \\
Godavari & $13.3 \pm 0.71^{\mathrm{a}}$ & $20.01 \pm 0.64^{\mathrm{a}}$ & $28.37 \pm 1.39^{\mathrm{a}}$ & $238.64 \pm 27.09^{\mathrm{a}}$ & $1085.88 \pm 37.41^{\mathrm{a}}$ & $17.61 \pm 0.19^{\mathrm{a}}$ & $43.67 \pm 1.45^{\mathrm{a}}$ \\
Narmada & $13.56 \pm 1.26^{\mathrm{a}}$ & $20.77 \pm 1.34^{\mathrm{a}}$ & $24.3 \pm 1.42^{\mathrm{b}}$ & $174.41 \pm 15.64^{\mathrm{b}}$ & $740.32 \pm 59.86^{\mathrm{b}}$ & $15.20 \pm 0.16^{\mathrm{b}}$ & $29.86 \pm 2.18^{\mathrm{b}}$ \\
\hline
\end{tabular}

The values (mean \pm SE) bearing same superscript do not differ significantly $(\mathrm{p}>0.05)$

\section{Acknowledgements}

The authors are extremely grateful to Dr. Gopal Krishna, Director and Dr. W. S. Lakra, former Director, ICAR-Central Institute of Fisheries Education (ICAR-CIFE), Mumbai for the continuous encouragement during the period of the research work.

\section{References}

Abdulraheem, I., Otubusin, S. O. and Olowofeso, O. 2012. Induced breeding of African catfish (Clarias gariepinus) under varying broodstock ratios. Global J. Sci. Front. Res., 12(8-D).
Adebayo, O. T. and Popoola, O. M. 2008. Comparative evaluation of efficacy and cost of synthetic and nonsynthetic hormones for artificial breeding of African catfish (Clarias gariepinus Burchell, 1822). J. Fish. Aquat. Sci., 3: 66-71.

Alonso-Fernandez, A., Alos, J. and Palmer, M. 2013. Variability in reproductive traits in the sex - changing fish, Coris julis, in the Mediterranean. Mediterr. Mar. Sci., 15(1): 106-114.

APHA 2000. Standard methods for examination of water and waste water, $21^{\text {st }}$ edn. American Public Health Association, Washington, DC, USA, $1268 \mathrm{pp}$. 
Argungu, L. A., Christianus, A., Nurul Amin, S. M., Daud, S. K., Siraj, S. S. and Rahman, M. 2013. Asian catfish Clarias batrachus (Linnaeaus, 1758) getting critically endangered. Asian J. Anim. Vet. Adv., 8(2): 168-176.

Bagenal, T. B. 1971. The interrelation of the size of fish eggs, the date of spawning and the production cycle. J. Fish Biol., 3(2): 207-219.

Bauwens, D. and Verheyen, R. F. 1987. Variation of reproductive traits in a population of the lizard Lacerta vivipara. Ecography, 10(2): 120-127.

Bhowmick, R. M. 1990. Hypophysation of Indian and exotic carps. In: Sugunan, V. V. and Bhaumik, U. (Eds.), Technologies for inland fFisheries development, ICAR-Central Inland Capture Fisheries Research Institute, Barrackpore, West Bengal, p. 15-24.

Blanck, A., Tedesco, P. A. and Lamouroux, N. 2007. Relationships between life-history strategies of European freshwater fish species and their habitat preferences. Freshwater Biol., 52(5): 843-859.

Brzuska, E. 2003. Artificial propagation of African catfish (Clarias gariepinus): Differences between reproduction effects after stimulation of ovulation with carp pituitary homogenate or GnRHa and dopaminergic inhibitor. Czech J. Anim. Sci., 48: $181-190$

Cheah, S. H., Siraj, S. S. and Ang, K. J. 1990. A preliminary study on induced spawning of the catfish Clarias batrachus (Linnaeus) in Malaysia. Pertanika, 13(1): 63-66.

De Graaf, G. J., Galemoni, F. and Banzoussi, B. 1995. The artificial reproduction and fingerling production of the African catfish Clarias gariepinus (Burchell, 1822) in protected and unprotected ponds. Aquac. Res., 26: 233-242.

Estay, F. J., Noriega, R., Ureta, J. P., Martin, W. and Colihueque, N. 2004. Reproductive performance of cultured brown trout (Salmo trutta L.) in Chile. Aquac. Res., 35(5): 447-452.

Fostier, A. and Jalabert, B. 2004. Domestication and reproduction in fish. Productions animales, 17(3): 199-204.

Garg, R. K., Sairkar, P., Silawat, N., Vijay, N., Batav, N. and Mehrotra, N. N. 2010. Assessment of genetic diversity of Clarias batrachus using RAPD markers in three water bodies of Bhopal. J. Environ. Biol., 31: 749-753.

Goswami, B. 2007. Magur (Clarias batrachus) seed production using low cost hatcheries: A participatory approach in Dakshin Dinajpur District of West Bengal, India. Aquac. Asia, 12(3): 14-16.

Goswami, U. C. and Sarma, N. N. 1997. Pituitary dose optimisation for induced ovulation, in vitro fertilisation and production of normal fry of Clarias batrachus (Linn.). Asian Fish. Sci., 10: $163-168$

Haniffa, M. A. K. and Sridhar, S. 2002. Induced spawning of spotted murrel (Channa punctatus) and catfish (Hetreopneustes fossilis) using human chorionic gonodotropin and synthetic hormone (ovaprim). Vet. Arhir., 72: 51-56.
Hossain, M. A. and Islam, M. S. 1990. The fecundity and sex ratio of the common punti, Puntius stigma (Cuvier and Valenciennes) (Cypriniformes: Cyprinidae) from the river Padma near Rajshahi (in Bangladesh). Rajshahi Univ. J. Zool., p. 69-74.

Hossain, Q., Hossain, M. A. and Parween, S. 2006. Artificial breeding and nursery practices of Clarias batrachus (Linn). Sci. World. J., 4: 32-37.

Islam, M. N., Islam, M. S. and Alam, M. S. 2007. Genetic structure of different populations of walking catfish (Clarias batrachus L.) in Bangladesh. Biochem. Genet., 45(9-10): 647-662.

Jagtap, H. S. and Kulkarni, S. S. 2015. Evaluation of breeding performance of Asian catfish, Clarias batrachus in captivity. Indian J. Sci. Res., 6(1): 73-75.

Kamler, E. 2005. Parent-egg-progeny relationships in teleost fishes: an energetics perspective. Rev. Fish Biol. Fish., 15(4): 399-421.

Khedkar, G. D., Reddy, A. C. S., Mann, P., Ravinder, K. and Muzumdar, K. 2010. Clarias batrachus (Linn. 1758) population is lacking genetic diversity in India. Mol. Biol. Rep., 37(3): 1355-1362.

Khedkar, G. D., Tiknaik, A., Kalyankar, A. D., Khedkar, C. D., Ron, T. B. and Haymer, D. 2016. Genetic structure of populations and conservation issues relating to an endangered catfish, Clarias batrachus in India. Mit. DNA, 27(2): 1181-1187.

Kiran, B. R., Murthy, S. K. and Venkateshwarlu, M. 2013. A review on induced breeding of catfishes, murrels and climbing perches in India. Adv. Appl. Sci. Res., 4(4): 310-323.

L'Abee-Lund, J. H. and Hindar, K. 1990. Interpopulation variation in reproductive traits of anadromous female brown trout, Salmo trutta L. J. Fish Biol., 37(5): 755-763.

Morgan, M. J. 2008. Integrating reproductive biology into scientific advice for fisheries management. J. Northwest Atl. Fish. Sci., 41: 37-51.

Oyelese, O. A. 2006. Water temperature - a determinant of fertilisation and hatchability rates in artificially induced breeding of Clarias gariepinus (Teleostei: Clariidae). Res. J. Biol. Sci., 1(14): 83-87.

Rao, G. R. M. and Janakiram, K. 1991. An effective dose of pituitary for breeding Clarias batrachus. J. Aquac. Trop., 6: 207-210.

Rottmann, R. W., Shireman, J. V. and Chapman, F. A. 1991. Hormonal control of reproduction in fish for induced spawning. United States Department of Agriculture, Southern Regional Aquaculture Centre, SRAC Publication no. 424 pp.

Sahoo, S. K., Giri, S. S. and Paramanik, M. 2013. Effect of carp pituitary extract dose and latency period combinations on the stripping response of Clarias batrachus (Linnaeus, 1758) during induced spawning operation. Indian J. Fish., 61(1): 128-130.

Sahoo, S. K., Giri, S. S. and Sahu, A. K. 2004. Effect of stocking density on growth and survival of Clarias batrachus (Linn.) larvae and fry during hatchery rearing. J. Appl. Ichthyol., 20(4): 302-305. 
Sahoo, S. K., Giri, S. S. and Sahu, A. K., 2005. Induced spawning of Asian catfish, Clarias batrachus (Linn.): Effect of various latency periods and SGnRHa and domperidone doses on spawning performance and egg quality. Aquac. Res., 36(13): 1273-1278.

Sahoo, S. K., Giri, S. S., Chandra, S. and Sahu, A. K. 2007. Effect of ovaprim doses and latency periods on induced spawning of Clarias batrachus: observation on larval deformity. Indian J. Exp. Biol., 45(10): 920-922.

Sharma, K., Yadava, N. K. and Jindal, M. 2010. Effect of different doses of ovatide on the breeding performance of Clarias batrachus (Linn.). Livestock Res. Rural Dev., 22(4): 1-7.

Shinkafi, B. A. and Ilesanmi, B. D. 2014. Effect of varying doses of ovatide on the breeding performances of African catfish (Clarias gariepinus Bruchell, 1822) in Sokoto, North-western Nigeria. Asian J. Anim. Sci., 8: 56-64.

Srivastava, P. P., Raizada, S., Daya, R., Chowdhary, S., Lakra, W. S., Yadav, A. K., Sharma, P. and Gupta, J. 2012. Breeding and larval rearing of Asian catfish, Clarias batrachus (Linnaeus, 1758) on live and artificial feed. J. Aquac. Res. Dev., 3(4): 2-5.
Svendsen, J. C., Banet, A. I., Christensen, R. H., Steffensen, J. F. and Aarestrup, K. 2013. Effects of intraspecific variation in reproductive traits, pectoral fin use and burst swimming on metabolic rates and swimming performance in the Trinidadian guppy (Poecilia reticulata). J. Exp. Biol., 216(18): 3564-3574.

Teletchea, F., Fostier, A., Kamler, E., Gardeur, J. N., Le Bail, P. Y., Jalabert, B. and Fontaine, P. 2009. Comparative analysis of reproductive traits in 65 freshwater fish species: application to the domestication of new fish species. Rev. Fish Biol. Fish., 19(4): 403- 430.

Thakur, N. K. 1980. Notes on the embryonic and larval development of an air breathing catfish Clarias batrachus (Linn.). J. Inland Fish Soc. India, 12(1): 30-43.

Tucker, C. S. 1991. Water quantity and quality requirements for channel catfish hatcheries. Southern Regional Aquaculture Centre Publication 461, Stoneville, Mississippi.

Yanong, R. P., Martinez, C. and Watson, C. A. 2009. Use of Ovarpim in ornamental fish aquaculture. University of Florida IFAS Extension, FA(161), 8 pp. 